\title{
Electoral Violence in Nigeria: Disentangling the Causes
}

\author{
ISAH MUSA YUSUF \\ Department of Political Science, Faculty of social sciences, Usmanu Danfodiyo University Sokoto, Nigeria
}

\begin{abstract}
The role and essence of elections in a democracy are highly circumscribed in terms of expressing the popular will, engendering political changes and the legitimating of political regimes. This role is fundamental to the thriving of most democracies. But when the precepts, structures and processes of elections are mostly characterized by reckless manipulations, the politics of brinkmanship and subversion, the tendency is to regard election not as a catalyst, but as a devalued element and a fading shadow of the democratic process. In Nigeria, for instance, electoral violence has become a worrisome phenomenon that has continued to rear its ugly head since Nigeria returned to civil rule in 1999. The violence becomes more pronounced before, during and after the announcement of election results. This has pushed the government to continue to seek for policy alternatives on how best to tackle electoral violence which most often degenerate into wide spread political violence. However unearthing the root causes of electoral violence is critical in achieving this goal. In this respect, causal drivers' framework will be adopted in analyzing electoral violence in this paper. While methodologically, field interviews conducted in sokoto as well as some secondary data from journals and media were analysed to empirically arrive at our findings. Thus, the study finds that while different but interrelated factors could breed violence; the tendency for elites' manipulation for personal gains by affecting the electoral process cannot be over emphasized in any our attempt to disentangling the causes of electoral violence in Nigeria. Each time Nigerian elites are excluded or disfavoured in the power configuration, the next line of action is to foment trouble by appealing to sentiments (ethnic, religion, party) and resorting to violent inducements.
\end{abstract}

Keywords: violence, election, electoral violence, democracy, politics

DOI: $10.7176 /$ RHSS/9-10-06

Publication date:May $31^{\text {st }} 2019$

\section{Introduction}

Beginning from Nigeria's general elections in 1964/65, violence became a major feature of electoral politics in the country. Consequently, the political contestation in Nigeria since the inception of civilian administration in 1999 has continued to be characterized by high degree of electoral violence. This trend of electoral violence has led to a situation whereby the citizens (Nigerians) view elections and democratic process with apprehension and anxiety, with popular confidence gradually being eroded in the electoral process. This is coupled with the potential capacity of electoral violence to impinge on the electoral process, undermine legitimacy and threaten democratic stability in Nigeria. The inability to conduct free and fair election has made the country the 'butt of bad jokes'(Adekanye, 1990) in the international community. Thus, with the polarization of Nigerian politics, electoral violence had increasingly become normal party strategy as politicians employed paid youths to coerce and intimidate electoral opponents during or immediately after election periods. The result has, therefore, been subversion of the democratic process rather than its sustainability and consolidation. Expectedly, major political and electoral violence have emerged around contestation over elections in Nigeria. The electoral and political landscape has moved from violence to greater violence. The level and magnitude of electoral violence in Sokoto state has risen and the political elites have converted poverty ridden unemployed youths in the state into readymade machinery for the perpetration of electoral violence. It is, therefore, against this background that this paper examines causes of electoral violence in Nigeria, with particular focus on Sokoto state between 1999 and 2009.

\section{The Causal Drivers Framework}

This study adopts the Causal Drivers Framework for analyzing election violence as developed by Sisk (2012). Causes-of-conflict analysis increasingly focuses on the underlying social and economic factors, or the intersection of "need, greed, and creed" in the attempt to theorize on election-related violence. In adopting this model, Sisk (2012) linked this more generic causal analysis framework of underlying social, environmental, or economic factors to the election violence research that emphasize the stakes, incentives and expectations of elites. To fully understand this framework, four points of analysis are critical: the context of democratization or political change in which violence occurs; the political economy of state power and the nature and patterns of political mobilization; the political economy of state capture; and the electoral system, integrity of electoral administration, and effects of violence management efforts such as peace pacts and security-force performance. In sum, the following features are discernible from the framework of analysis for electoral violence discussed above; the context of democratization matters because the use of violence is strategic to a broader purpose. The 
political economy of state capture relates to the deep structural conditions that inform the stakes of controlling the commanding heights of governmental authority in high natural resources environments. The electoral system is important because it determines who wins, how and by how much. It is often specifically manipulated for a specific aim. And finally, the question of electoral administration is critical because fraudulent or poorly administered elections are more likely than fair elections to produce challenges of illegitimate rule.

The relevance of this theory is underscored by the fact that in most African countries, the various conflicts that usually develop during the democratization process are mostly of the elite kind, which in Nigeria is essentially organized around competing materialistic interests of various sections in the society. That soon after, the political environment was hostile to development and internal struggle for power was the absolute focus that led to electoral violence.

\section{Democratization and Electoral Violence in Nigeria}

Elections ideally reflect and impact on the orderliness within society and the possibility of rejuvenating the political leadership through the change of decadent members of the elite and the advancement of the non-elite element. Properly managed elections provide a veritable platform for conflict resolution and transformation (Odukoya, 2007). Unfortunately, in Africa and Nigeria in particular evidences suggests that elections are fast becoming the very opposite of the above. Odukoya (2007) further pointed out that while much lip-service is paid to norms of free elections, too often the reality is a travesty of democracy. Devoid of the attribute of freeness and fairness, elections become empty shells, lacking any real democratic content.

Commenting on Nigeria's elections, Aluaigba (2008:2) maintained that credible election most relevant to the quality of democracy has been dented with terribly festering irregularities. This explains why the conduct of free and fair election has remained elusive and problematic in Nigeria since independence. He further argued that public polls held in 1959, 1964-65, 1979 and 1983 were all fraught with various levels of anomalies ranging from bribery, electoral violence, intimidation and harassment of voters, ballot box snatching and ballot stuffing, under age voting, vote buying, and so on. This misdemeanor has cost Nigeria its political stability, leading to military coups that over-threw the civilian regime. It is clear that this trend has not changed as exemplified by the 1999, 2003 and 2007 elections in the country.

Emerging from the above is that electoral violence has become a prominent feature in most democratization processes and with catastrophic effects on democracy or democratic consolidation. As an element of conflict, violence is in existence in one form or another in every society and every institution of societies but the persistence of electoral violence signifies a draw-back in a country's democratic journey.

Studies of election-related violence (Olaniyi, 2001) often highlight the perpetuation of patronage politics or a system in which politicians are gang-like bosses that control resources (such as access to jobs and income) and dispense public service such as housing, health care or lucrative government contracts.

Indeed, Olarinmoye (2008) maintained that electoral corruption is the result not just of the avariciousness of god fathers and politicians but of the logic of electoral competition (zero sum) which demand that political parties in Nigeria resort to individuals (god fathers) to effect electoral success through activities that distort the electoral process. Thus, the stakes of election are often seen as opportunities to engage in corruption and economic rent-seeking. This, in turn, leads to highly factionalized politicians, often along religious, sectarian, or ethnic lines or along party political divides, where control of the state leads to the reinforcement of class divisions or economic opportunities along lines of social difference.

Struggle in politics is a normal phenomenon since it has to do with competition, what is abnormal is the violence that has engrossed political struggle and power relations in Nigeria. Electoral violence is motivated by political actors who see politics not only as do or die affairs, but also as an extension of birth rights of individuals or group and so real or imagined opposition is silenced, worst still, eliminated. For the purpose of political recognition and relevance, well-placed individuals and groups continue to enjoy tenacity of office at the detriment of other 'disadvantaged' groups and individuals. Politics and political relations become stressed and strained. Intolerance ensues rather than accommodation; rancour rather than harmony and conflict in place of cooperation.

Electoral violence is gradually becoming a permanent feature of democratization in Nigeria. This is because most campaign grounds are soaked with violence and killings. Arowolo and Aluko, (2012) argued that electoral violence seems to be institutionalized since it emanates from the corridors of power and so politics and political activities become exclusive rights of the politicians who make politics dirty in the first place. The fact that political game in Nigeria is played at variance with set rules makes it a dirty game. They maintained that Politics in Nigeria must have been infested with greed, tribalism, intolerance, injustice and parochial instinct of political leadership.

It is only natural and expected, therefore that in a situation where political opponents are clamped down upon like in Nigeria, the political space becomes heated and tension-soaked as opponents strive to balance the terror. Indeed Arowolo and Aluko,(2010) maintained that from 1999 to 2011, election into political offices was 
constantly secured by those who had the monopoly of weaponry and thuggery, as violence, rather than the electorate determined who occupied what position.

Commenting on reasons for escalation of electoral violence in Nigeria, Tamuno (2003) gave primacy to the fact that it was only the industry of politics as practiced in Nigeria that promised or delivered to the lucky ones the scarce commodities of wealth, power and fame, which he believes are the three dividends of public office holding at all elective levels in Nigeria. It is in this vein, that Tijjani (2003) also maintained that political and election-related violence is nothing but an expression of the deeply-seated culture of corruption in Nigeria. Therefore, political contests become fiercer than necessary in game where winners took all and losers become more desperate to such an extent that they could hire assassins, readily available among the poor not gainfully employed to do dirty jobs for the rich and angry politicians.

The culture of violence in some societies predisposes them to electoral violence. The prevalence of violence during election season in Africa has been explained within the context of democratization process in the continent. The several decades of military and authoritarian colonial rule has impacted on the electioneering process in most of Africa's new democracies. The decades of military/authoritarian rule resulted in a strong military dominating virtually all spheres of the society (economy) giving them a vantage position over their civilian counterpart in the struggle for power in civilian dispensation (Adekanye, 2000). Civilian political leaders emerged with military mentality. The use of violence during election season is seen as justified as an instrument for competing against opponents in the struggle for power in the relatively new democracies in Africa. Electoral violence has increased by 50 percent in Africa from 1990 to 2006 compared to time between 1945 and 1989 . According to the NELDA data set of national elections, ranging from 1945 to 2006, between 1945 and 1989 there were 352 election events, of which 66 or 18.75 percent were marred with electoral violence that involved civilian deaths immediately before, during or after the elections. Between 1990 and 2006 there were a total of 330 election events of which 93 (or 28.18 percent) involved electoral violence (Hyde and Marinov, 2012).

Osaghae (1989) identifies the form and character of the state as implicating factors toward electoral violence in Nigeria. For him, states that are totalitarian such as most African states, where the exercise of powers of the state is based on the use of force; capturing political power translates to capturing all other things. When these states embrace democracy, the character of the state remains and is still evident. The result eventually is unhealthy rivalry and competition for power during elections.

Stiftung (2001) in a report on the conference for political and electoral violence in East Africa presented his argument on electoral violence using specific themes: for him electoral violence can assume different nature ranging from fighting hooliganism, disruption of campaign rallies, threat of violence, political thuggery, abduction and kidnapping to the most like murder, killings, assassinations, assault, battery, bombings destruction, looting and damage to property. The causes of political and election violence identified cut across factors such as political greed and repression, bias and partiality of the electoral commission and lack of credibility of the electoral body to such issues as poverty, illiteracy, incitement and ethnicity which makes the populace susceptible to political manipulation by politicians.

Political parties, electoral management bodies and the judiciary ideally are supposed to be tools for social mobilization, transparent electoral governance, and effective electoral justice system respectively. In most cases, especially in the emerging African democracies, the reverse is the case. Political parties are not ideologically based to effectively mobilize voters. This inadequacy gives room for other forces of mobilization such as ethnicity and religion which are usually manipulated and are prone to violence (Basedau et al, 2007). Electoral Management Bodies (EMBs) in their composition are supposedly impartial, independent and transparent but their funding and composition is determined by the government and has political affiliation. This casts doubts on their independence by opposition parties. Consequently, rejection of election results by opposing parties/candidates, results in outbreak of violence because of perceived manipulation of EMBs by the incumbent (Ijim-Agbo, 2007).

In examining the potential determinants or conditions that fuel violence in connection to polling, Lyons (2005) identifies the context within which conflict occurs in the electioneering process. In conflict societies, elections are contested fiercely because of the perceived stakes involved. Violence thus becomes an attractive tool to garner votes in an election. Also, the competition between parties during electioneering process may invite the use of violence as a way out of accepting electoral defeat. The culture of violence and impunity which characterizes conflict societies further fuels the situation since perpetrators of electoral violence are not brought to book because the political parties are afraid of losing their support.

A country's electoral administration and electoral system are crucial to explaining the attractions of violence in some societies and among certain actors. In systems where a small percentage of the votes are determinant of the outcome for the election, for instance, in system such as first-past-the-post electoral system violence is likely to occur (Reif, 2005; Reilly and Reynolds, 2000). Also the kind of election whether it is a referendum, a local or national (presidential/parliament) election will influence the pattern of electoral competition and the likelihood to use violence. The independence of the Electoral Management Bodies (EMBs) 
whether they are run by government, under government supervision or strictly independent of government control. Lastly, the choice of electoral administration may influence the use of violence during election because of the suspicion and mistrust. Socio-economic condition of the citizens is also one of the key drivers of violence in Nigeria. Nigeria is a wealthy country with the poor of the poorest population. Most citizens live on less than \$2 per day, maternal mortality is high, and there is widespread unemployment. Hence, resource based competition is one of the underlying reasons for electoral violence. Citizens compete for jobs, land, oil profit etc.

Bekoe (2010) implicates some underlying grievances or structural characteristics for the regularity with which electoral violence occur. These structural factors includes: grievances over land rights, jobs and ethnic marginalization are manipulated by politicians in pursuit of their political ambition. In the same vein, Biegon (2009) observes that electoral violence is not an independent phenomenon of occurrence; rather it is a product of historically dysfunctional political relationships and structural factors. It is clearly a part of a larger problem of fragile political, economic and social systems. This in turn, further weakens an already fragile state or society.

As Adetula (2007) observes, while electoral violence may occur before or after electoral competition, at their base are protests and agitations over socio-economic issues. Invariably, the lure for these resources creates a ready supply of people to perpetrate violence in order to get those resources. The level of poverty with its attendant problems of unemployment, restlessness etc predisposes societies to violence. The logic is that democracy thrives under some level of economic development, the absence of this have dire consequences for democratization in Africa. The situation makes people easily vulnerable to the antics of dubious politicians who may want to use them for thurggery to achieve their political objectives (Omotola, 2008). Bamfo (2008) in his study identifies the sit tight syndrome of political leaders. That is, the tendency to hang on to power at all costs, no matter what it takes, even if it means using violence to manipulate elections.

\section{Explaining the Prevalence of Electoral Violence in Sokoto State}

Generally, the factors responsible for electoral violence in Sokoto State are not much different from the causes of electoral violence elsewhere in Nigeria. These factors can be broadly categorized into two: the structural factors relating to the underlying power structures prevalent in Nigeria and; secondly, the factors related to the electoral process and the electoral contest itself. These are, however, not mutually exclusive. The factors will now be considered as follows:

The first factor identified by our respondents is the stakes of political competition and the nature of contestation for power. Essentially, the Nigerian state is a law and order state, predicated upon the use of force to enforce its decisions. The state has domineering power over the society in every facet of life. Capturing political power, therefore, translates to capturing all other things. One respondent noted that the increasing centralization of power in the Presidents at the national level, Governors at the state level and Political leaders at other levels of governance tends to heighten political stakes. The result is the unhealthy competition for power since political power has become the main key to all other sources of power, thus resort to violence (Interview: Aliyu, 2012). Nothing illustrates this better than the abuse of power of incumbency in an effort to remain in power at all costs, and if all else fail, to impose a surrogate that will continue to defer to the good judgment of the benefactor. Ake (1996:73), for instance, argued that:

The state is in effect privatized. It remains an enormous force but no longer a public force, no longer a reassuring presence guaranteeing the rule of law but a formidable threat to all except the few who control it, actually encouraging lawlessness and with little capacity to mediate conflicts in society.

In the circumstance where the state is privatized, those in power will use violence and state repression apparatuses to retain power. The people excluded from governance (especially in a society where politics is a license to oppress other citizens and to loot treasury) will resort to violence in their quest for office.

The second factor in explaining the prevalence of electoral violence in Sokoto State, and which is closely related to the first, is the weakness of the economic foundation of democracy. Democracy requires some level of economic development, particularly with respect to income and poverty levels. When the poverty level is higher than a standard threshold at $\$ 2$ a day for the poverty line and $\$ 1$ for absolute poverty, democracy may be at risk (Omotola, 2008). Unfortunately, poverty remains a continent-wide problem, and Nigeria seems to face the greatest challenge despite its increasing oil revenue. For instance, between 2000 and 2009, the price of crude oil which has contributed about $80 \%$ of the country's GDP rose from $\$ 13$ per barrel to a high of $\$ 125$ per barrel. The significance of this rise is evidenced by the total oil revenue generated into the Federation Account from 2000 to 2009 which amounted to $\$ 34.2$ trillion while non-oil revenue was $\$ 7.3$ trillion (CBN, 2009).

It is disturbing that in 2002, Nigeria was one of the 21 poorest countries in the world. In 2003, a staggering $70 \%$ of the population were said to be living below poverty line. In 2008, official statistics claims some reduction to about $60 \%$, a contestable claim given prevailing realities, including rising inflation and unemployment. The depth of the crisis is evident in the fact that if 'Nigeria succeeds in just preventing the worsening of poverty, a tall task given current trends, it would still have some 170 million poor people in 2015' 
(Okonjo-Iweala et al, 2003:7). Estimates indicate that Nigeria would require an annual Gross Domestic Products (GDP) growth rate of 7 to $8 \%$ in order to halve the number of people living in poverty by 2015 (Omotola, 2008). Meanwhile, [...] between 2004 and 2010, Nigeria's poverty rate had moved from $54.4 \%$ to $69 \%$ involving about one hundred and twelve million Nigerians, although the country's GDP had grown since then, it had little impact on the poverty situation (Nigerian Tribune, $13^{\text {th }}$ February, 2012).

Furthermore, the North-West and the North-East geopolitical zones had the highest poor; the South-West recorded the lowest with $59 \%$. Again, whereas Sokoto State tops the list of poor states with $86.4 \%$, Niger state followed with $43.6 \%$ in the year under review (Nigerian Tribune, $13^{\text {th }}$ February, 2012). It is very glaring that situations like this tend to make people easily susceptible to diverse forms of negative mobilization at the slightest inducement, including electoral violence. In an interview with a respondent who worked as a Returning Officer for INEC in Sokoto during the 2011 elections in the state, the following comment was made by the interviewee:

What usually makes people to involve in election crises are poverty and unemployment. For instance, in Sokoto State, $75 \%$ of the youths are jobless. If you don't have anything to do and you don't have money, definitely you will be in poverty. If somebody come and give you money and ask you to do evils, you will do it (Interview: Gobir, 2012).

In another interview, the respondent maintained that due to economic decline in the State, there are too many people who are ready to be recruited by the politicians to be used as agents of violence (Interview: Baba, 2012).

Another interviewee arguing in this same direction avers that:

It is a common knowledge that the youth who readily submit themselves to perpetrate these acts of thuggery are unemployed and wallowing in poverty. For many of them, some good promises are made relating to job expectations or contracts awards. For some, it is for some paltry sums of money paid to hire them. The dirty jobs these thugs do are not the kind of jobs gainfully employed people or literate people will be involved in. Not even the children of these politicians will go into the field to be directly involved in these acts of thuggery for the sake of ensuring victory for their parents (Interview:Godwin, 2012).

Yet, another interview with the former Sokoto State DPP supporter affirms that:

There are many factors responsible for violence in Sokoto politics. They include poverty, joblessness and bad economy among others. Someone who cannot afford three square meals, if you give him money and tell him to kill, will he not? This is because those people are poor and have no hope for tomorrow. During former Governor Bafarawa's tenure, thuggery reduced in Sokoto but when these people (Wamakko's regime) took over a lot of people who did not go to school, jobless persons and thugs were used to have their ways. They armed them with dangerous weapons such as daggers and cutlasses... if you are not on their side, you will be attacked and nothing will be done to redress the situation. Violence is their mainstay for having their ways. They cannot do without thugs. (Interview: Muhammed, 2012).

In another interview with a PDP supporter in Kware Local Government, the following comments also shed light in explaining the occurrence of electoral violence in the state:

There are three main reasons why violence is predominant in contemporary political affairs. The first is the bad state of the economy, which has left many able bodied people without work and do not forget an idle hand is the devils workshop. The second is our poor political culture and perception. We are products of a system that believes that when the political patron talks, everybody bows. Anybody who says otherwise will be seen as an enemy who has to be resisted. The third is the over attractiveness of political offices for economic reasons. That is why people want to put in everything they have whether moral or immoral (Interview: Ibrahim, 2012).

From the foregoing, it is evidently clear that poverty pervasiveness hastens the occurrence of electoral violence. The massive poverty that engulfs the body polity is a great asset to the politicians. The alarming rate of unemployment gives youth away as willing tools for the perpetration of violence with little financial inducement. The endemic poverty easily plays the gullible youths into the hands of unscrupulous politicians, who manipulate them, dangling irresistible baits for the youths to undertake electoral violence.

The third factor or reason for electoral violence is corruption. Although it is difficult to agree on a precise 
definition, there is consensus among scholars that corruption refers to acts in which the power of public office holder(s) is used for personal gain in a manner that contravenes the rules of the game (Ogundiya, 2012). Corruption, is therefore, popularly conceived as the improper use of influence in order to gain undue personal or group advantage. It involves behaviors or acts undertaken with the intention of deriving personal rewards against the interests of the state such as theft, embezzlement of funds or other appropriation of state property, nepotism and abuse of office to exact monetary benefits or other privileges.

Corruption is not a new phenomenon in Nigeria. Nigeria is a nation submerged by corruption. Right from independence, the country has been presided over by the ruling elites who put its narrow interest far above the interest of the masses. Consequently today, Nigeria is placed $143^{\text {rd }}$ in the 2011 ranking making it the $37^{\text {th }}$ most corrupt country according to Transparency International (TI). Corruption has become fashionable to the extent that the more a politician steals, the more popular he/she becomes among the kleptomaniac political elites and ignorant itinerant area boys and political thugs.

Indeed, it has been observed that corruption is entwined with political/electoral violence in Nigeria. Public revenues are not only stolen, but are often used to pay for the services and weapons used for violence. Also, it has been reported that between \$4 billion to \$8billion per year was lost to corruption between 1999 and 2007 in Nigeria and substantial parts of this have gone into fomenting violence and trouble by politicians in their bid to continue to hold on to political posts even after the electorate have rejected them (Ugiagbe, 2010:1). Also, in line with this assertion, Ogundiya (2012:57) maintained that:

Since access to state wealth is guaranteed by elective and appointive positions, political appointments and elections have become do or die affairs. Cut throat rivalry manifesting in political assassinations, contract killings has become the order of the day. Political instability defined as the entrenched crisis in the social, economic and political make-up of a state has been the hallmark of Nigeria's democratic project since 1999. Viable economic policies cannot be predicated on a fragile political base. Over 10000 Nigerians have lost their lives in corruption instigated ethno-political conflicts across the country.

The fourth factor in the occurrence of electoral violence is the money politics and financial gains. Here, the lucrative natures of political offices are alarming. It is so enormous that aspiring politicians to certain offices do whatever is possible to get there. Due to the get-rich-quick syndrome characteristically commonplace in Nigeria, politics has become such a lucrative business so much that it is now a matter of do-or-die in the struggle to acquire political power. Remuneration for political offices being exceedingly attractive constitutes the major reason most politicians contest elections. Even if the mandate is denied them as expressed in voting where there is any, they steal it through acts of thuggery and violence.

The former Governor of the Central Bank of Nigeria (CBN), Sanusi Lamido Sanusi once cried out that the National Assembly only in the 2010 Federal Governments budget had an overhead of $25.1 \%$, in $2009,19.8 \%$ and in 2008, it was $14.19 \%$ (Leadership, 2010). He further revealed that if the Federal budget is looked at, the bulk of government spending is on recurrent expenditure and it is a big problem as 25 percent of the overhead of the Federal Government goes to National Assembly (Leadership, 2010).

Statistics have also shown that a Nigerian Senator earns more in salary than the President of the United States of America (USA) and the Prime Minister of the United Kingdom (UK). It may be recalled that with the global economic recession, it took the late President Umar Musa Yar'adua to formally propose salary cut for the National Assembly. Before then, a Nigerian Senator earned at least 8 times as much as an American Senator and more than 3 times the American President. With the reduced salary, pay package a Nigerian Senator is said to still get paid $\mathrm{N} 11$ million $(\$ 73,333)$ in regular salaries and allowances annually and N152 million $(\$ 1.03 \mathrm{~m})$ in four (quarterly) allocation making a total of $\$ 1.11$ million plus irregular allowances like estacodes and duty tour allowances (Shanky-Ula, 2010). The story is not different regarding of the executive arm of government and this trend runs from the Federal level through state to local government levels.

From the foregoing, it is clear that the attractive nature of public office engenders investment mentality. Political investors and other major financiers of the political process for individuals seeking political office expend huge sum of money on the electoral process with expected return. Therefore no amount is too much to use in instigating electoral violence, even expending the lives of opponents and valueless youths.

The fifth factor identified as one of the major causes of electoral violence is the weak institutionalization of some key architecture of democratic politics. The most notable institutional architectures of democracy are political parties, Electoral Management Bodies (EMBs) and the judiciary. The political parties are supposed to be erected on a specific political ideology that will serve as its organizing and mobilization anchorage. In the absence of one, other tools of mobilization particularly forces of identity such as ethnicity and religion become appealing. The glaring ideological barrenness of most parties in Nigeria, and the attendant decadence of political parties, which manifest in the gross absence of internal party democracy and the heavy reliance on negative 
mobilization to win elections, underlies electoral violence in Nigeria.

Lack of party discipline in political parties' competition in Nigeria has also contributed to violence. For instance, the conducts of primaries in most parties are devoid of adherence to rules, to parties' policies and directive. The result of this is extreme rivalry, fractionalization and multiplication of parties by the aggrieved members of a party as has been witnessed in the democratic processes of Sokoto State as mentioned elsewhere in this chapter. Again, the language of political campaign by politicians has contributed in no small measure to fuelling conflict and inciting violence in political party competition. The political atmosphere is always charged with grievous and provocative utterances of political leaders. We are familiar with the rhetorical excesses of former President Olusegun Obasanjo's declaration of the 2007 General Election as a "do or die affairs" for his party PDP and in terms of unparalleled arson and killing that attended the election. Such ominous usages by the president include 'no corrupt politician will ever win election again'; 'I will declare national emergencies'. Other equally worrisome remarks are 'we will not sit idly by', if anybody tries to change your vote, change the person to dust'. Also former Governor Ahmed Bola Tinubu of Lagos state at the flag off of the AC governorship campaign at Amuwo-Odofin area declared that 'if it is war, we will give it. If they want peace, we will give it. If they want riot, we will give it. If they want dead body, they will get it (Umar, 2007).

Likewise, in run off towards the 2011 election, a tense political atmosphere is already building up with the utterances of various gladiators for the office of the president of the country. For instance, incumbent President Goodluck Jonathan commented that 'those who are ganging up against him will fail' Atiku, the former Vice President, retorted that 'the president is polarizing the nation', to mention a few (The Sun, 2000:1). In the same vein, an interviewee noted that;

Mere refusal to say "Sai Alu" (Campaign slogan) during the electioneering campaign processes here in Sokoto could result in serious intimidation and sometimes serious thuggery by the Area Boys supporting AliyuWamakko (Gubernatorial candidate). While at the same time mentioning "Sai Alu" in the midst of Area Boys supporting Bafarawa and his associates can cause you serious harm (Interview: Abubakar, 2012).

Apart from the language of political campaign, electoral fraud represents another notably immediate cause of crisis and violence in electoral competition in Nigeria. Most incumbents of government offices often relied on these malpractices to retain their seats or hold on to power than seeking people's votes. The list of the various malpractices identified by our respondents include vote buying, vote rigging, illegal and fake voters, register and voters cards, fake ballot boxes, snatching of ballot boxes, stuffing of ballot boxes, multiple and underage voting, intimidation by party agents and security officials, among other vices. However, while all these frauds are being perpetrated, security officers sometimes look the other way or even take active part having agreed in deals with concerned parties.

On this note, one of the INEC officials interviewed in Sokoto while commenting on the 2012 gubernatorial election noted that:

INEC as an organization had a list of identified flash points known for recurrence of violence, thuggery, and area boys. INEC gave the police all that information and the police still posted nobody to these areas. Instead, they were seen at road blocks, when they were needed in polling units. The security scare particularly the presence of area boys, influenced a lot of irregularities. I wouldn't score the police twenty percent (Interview: Anonymous, 2012).

It is the frustration that attends the open impunity of these electoral frauds that in most cases triggers the wild violence that results from electoral competition in the country. The insincerity of law enforcement agents and outright inefficiency in arresting offenders has therefore, contributed to culture of impunity and encourage more violence in the country.

With respect to the Electoral Management Bodies (EMBs), the situation seems even worse. This is because effective electoral governance requires impartiality, independence, efficiency, professionalism and transparency of the EMBs to avoid mutual suspicion and mistrust among political actors. These issues can be determined by the mode of composition of the EMBs, their funding and motivation. The Independent National Electoral Commission (INEC) in Nigeria, is constituted by the president, does not have an independent source of funding and therefore, depends on the presidency, and has political affiliations. INEC appears thus like a mere appendage of the presidency, which wields overbearing influence over it. This makes it easy to manipulate EMBs to serve the interests of the incumbents to the disadvantage of opposition parties. As observed by Omotola (2008:67),

INEC attempted to illegally disqualify AbubakarAtiku from contesting the 2007 election at the instance of the presidency. It took the intervention of a landmark Supreme Court judgment a couple of days before the election to reverse the decision. In several states, including Kogi and Adamawa states, 
INEC succeeded in disqualifying some opposition candidates, getting those elections nullified by the court, and calling for a rerun.

Therefore, issues such as the manipulation of EMBs by the incumbent power holders feature prominently in the rejection of election results and eventual outbreak of violence in Nigeria. For instance, the opposition parties rejected the 2007 and 2011 elections alleging manipulation of the EMBs by the ruling party. It is instructive to note that though on the verge of the 2011 elections, some of the recommendations of the electoral reform acts were adopted through the restructuring of INEC and appointing an academician, Professor Attahiru Jega to head the body and giving the commission a degree of financial support, such moves were never far reaching and did little to curtail the allegations of manipulation of INEC by the incumbent party.

Another factor responsible for electoral violence is the problem of electoral justice. In Nigeria, the electoral laws spell out the procedure and conditions of seeking electoral redress in courts. The burden of proof lies with the litigant, and a major requirement is that it must be proved beyond any reasonable doubt that the alleged irregularity was substantial to warrant nullification of the elections. These are near impossible conditions for obvious reasons. For one thing, the cost of electoral prosecution is no child's play, so that those outside government may not be able to afford it. For another, the declared winner of the contested election is already sworn-in, with full paraphernalia of office while the legal tussle lasts. This already tilts the electoral justice landscape in favour of the winner, who not only has access to state resources, but also takes full advantage of them to prosecute a personal case. In such circumstances, the huge cost and the burden of proof constitute limitations to the litigants. As one interviewee noted, obviously, the fact that Aliyu Wamakko was already sworn-in with full paraphernalia of office and public funds at his disposal, contributed immensely to his success in the court against Maigari Dingyadi of the DPP (Interview: Musa, 2012).

So also is the problem of corruption which has reared its ugly head in the judiciary and manifests in the allegation of grafts against some judges. A case in point is the bribery allegations at the judiciary with respect to the person of the former Chief Justice of Nigeria, Justice AloysiuKatsina-Alu by the then president of the Federal Court of Appeal, Justice Ayo Salami with regard to the Sokoto state governorship election petition (Vanguard, July $15^{\text {th }}, 2012$ ).

Despite, several electoral fraud and violence that characterize most elections in Nigeria, most petitions were hardly successful. Unfortunately, the failures were not for want of compelling evidence, but due to the impossibility to prove that the fraud was substantial to alter the results. But reports of local and international monitoring teams usually attest to the monumental fraud and violence that characterizes elections in Nigeria. As Omotola, (2008:67) noted,

$[\ldots]$ the political economy of electoral fraud and violence tends to be more rewarding than that of electoral justice in Nigeria. This tendency provides some incentives to play along, given that securing electoral justice in the face of these challenges seems an impossible mission.

From the foregoing, it is all too obvious that candidates in an electoral contest and their supporters resort to violence instead of embarking on an endless venture as the impartiality of the judges at the tribunal are in doubt. Where elections are not struck out on technical ground, they are protracted for a long period that is not guaranteed.

In the same vein, some respondents linked the high spate of electoral violence in Sokoto to ineffective law enforcement arguing that non enforcement of laws and non-adherence to same in the electoral process promotes violence during elections; due to the lack of political will by the political class. An interviewee noted for instance that political actors, political players, party supporters and political thugs violate the laws that govern the rule of politicking with impunity due to inability of the government and other law enforcement bodies to compel obedience. He noted further that when the administrators of the political processes are unwilling to enforce the rules, a lot of opportunities are created for violence and if the law does not prevail, it is almost the same as there is absence of rules to govern the conduct of elections (Interview: Danlawan, $16^{\text {th }}$ October, 2014). Therefore, election violence is persistent in Nigeria not only because of the apparent culture of impunity from prosecution, but also inaction by the security personnel on the scenes of crimes during campaign periods. Furthermore, incumbents and their supporters are often not apprehended by security personnel when seen committing election offences. Weak legal framework in Nigeria is a fulcrum upon which the culture of violence is built and sustained.

\section{Conclusion}

From the above examination of the causes of electoral violence, a major conclusion of this paper is that while several factors accounted for the occurrence and subsequent rise in electoral violence, the selfish interest of the political class is very vital in understanding the unending nature of this violence in Sokoto state. Most of these factors whether institutional or procedural cannot exist independent of the inordinate ambitions for power and crass materialism among the political elites. One cannot but agree with Ake (1996) that they are linked to the high value placed on politics in the country with devastating effects for the democratic project. This is in the 
sense that politics determines almost everything in the country and that those who control political power determines who get what, when and how in the Nigerian society.

\section{References}

Adekanye, J.B. (1990). "Elections in Nigeria: Problems, Strategies and Options". Nigeria Journal of Electoral and Political Behaviour. Vol.1. No.1.

Adekanye, J.B. (2000). Retired Military as an Emergent Power Factor in Nigeria. Ibadan: Heinemann Publishers.

Adetula. V.A.O. (2007). "Election Related Violence in Nigeria: Survey of Trends and Pattern in the 2007 Elections" Studies in Politics and Society Journal of Nigerian Political Association. Vol.8:224-257.

Ake, C. (1996). "The Political Question" in Oyediran, O. (ed). Governance and Development in Nigeria: Essay in Honour of Professor Billey Dudley. Ibadan. Agbo Areo Publishers.

Aluaigba, M.T. (2008). "The Travails of an Emerging Democracy: The Turbulent 2007 General Elections in Nigeria". Paper Presented at $67^{\text {th }}$ Annual Conference of the Midwest Political Science Association, Illinois, USA. April, 2-5.

Arowolo, D.E. and Aluko, O.A. (2012). "Democracy, Political Participation and Good Governance in Nigeria". International Journal of Development and Sustainability. Vol.1. No.3. Pg.797-809.

Bamfo, N. (2008). "Electoral Violence in Africa". Conference Proceedings. Valdosta State University: Georgia Political Science Association.

Basedau, M; Gero, E; and Andreas, M. (2007). Votes, Money and Violence: Political Parties and Elections in Sub-Saharan Africa. Durban: Nordic African Institute and University of KwaZulu-Natal Press.

Bekeo, D.A. (2010). Trends in Electoral Violence in Sub-Saharan Africa. Washington DC: United States Institute of Peace Press.

Biegon, J. (2009). "Electoral Violence and Fragility in Africa: Drawing Lessons from Kenyan's Experience in the 2007/2008 Post-Election Violence". A Paper Presented at the Conference on Financial Markets, Adverse Shocks and Coping Strategies in Fragile Countries. Accra: Ghana. May, 21-23.

Central Bank of Nigeria. (2009). Economic Report for the $4^{\text {th }}$ Quarter. Vol.4. Issue 4. December.

Hyde, S.D. and Marinov, N. (2012). 'Which Elections can be Lost”? Political Analysis. Vol.20. No.2. Pg.191210. Oxford University Press.

Ijimi-Agbo, U. (2007). "The Independence National Electoral Commission As An (Im) Partial Umpire in the Conduct of the 2007 Elections". Journal of African Elections. Vol. 6(2):79-94.

Leadership Newspaper. (2010). Abuja: March, $14^{\text {th }}$.

Lyons, T. (2005). Demilitarization Politics: Elections on the Uncertain Road to Peace. Boulder: Lynne Rienner Publishers.

Nigerian Tribune. (2012). Ibadan: February $13^{\text {th }}$

Odukoya, A. (2007). Democracy, Elections, Election Monitoring and Peace-Building in West Africa. African Journal of International Affairs. Vol.10. Nos.1\&2.

Ogundiya, I.S. (2012). "A Nation in the Wilderness: Corruption, Elite Conspiracy and the Illusion of Development in Nigeria" in Abdulrahman, D.A; Ogundiya, I.S; Garba, T; and Dankani, I.M (eds). 50 Years of Nigeria's Nationhood: Issues and Challenges for Sustainable Development. Ibadan: Crown F Publishers.

Okonjo-Iweala, N, Soludo, C. and M. Mukhtar (eds) (2003). The Debt Trap in Nigeria's: Towards a Sustainable Debt Strategy. Trenton: Africa World Press.

Olaniyi, O. (2001). Introduction to Contemporary Political Analysis. Lagos: Fapsony Nigeria Limited.

Olarinmoye, O. (2008). Godfathers, Political Parties and Electoral Corruption in Nigeria. African Journal of Political Science and International Relations. Vol.2(4).

Omotola, S. (2008). "Electoral Reform, Political Sensation and Democratization in Africa". Paper Presented at $27^{\text {th }}$ Annual Conference of the Nigeria Political Science Association (NPSA), Benue State University, Markudi. November, 16-19.

Osaghae, E.E. (1989). "The Character of the State, Legitimacy Crisis and Social Mobilization in Africa: An Explanation of Form and Character". Africa Development. Vol.14, No.2. Pg.27-53.

Reif, M. (2005). "Electoral Violence as a Political Strategy: how Institutions define and how have been defined by electoral Conflict in Mature and Emerging Democracies". Dissertation Summary. (Unpublished Paper).

Reilly, B and Reynolds, A. (2000). "Electoral Systems An Conflict in divided societies" in Stern, P.C and Druckman, D. (eds). International Conflict Resolution after the Cold War. Washington DC: National Research Council.

Shanky-ula, T.S. (2010). Political Thuggery and Elections in Nigeria's and The Lawen Law and Security in Nigeria. Lagos: Lens Publications.

Sisk, T.D. (2012). "Evaluating Election-Related Violence: Nigeria and Sudan in Comparative Perspective" in Bekoe, D.A. (ed). Voting in Fear: Electoral Violence in Sub-Saharan Africa. Washington DC: United 
States Institute of Peace Press.

Stiftung, E. (2001). "Political and Electoral Violence in East Africa". Working Paper on Conflict Management. No.2.

Tamuno, T.N. (2003). "Historical Antecedents of Political Violence in Nigeria" in Jega, A.M;

The Sun Newspaper. (2010). Lagos: January $9^{\text {th }}$

Wakili, H. and Umar, M.A. (eds). Strategies for Curbing Election-Related Political Violence in Nigeria's NorthWest Zone. Kano: Mambayya House.

Tijjani, K. (2003). "Strategies for Controlling Political Violence and Regulating Campaigns" in Jega, A.M; Wakili, H. and Umar, M.A. (eds). Strategies for Curbing Election Related Political Violence in Nigeria's North-West Zone. Kano: Mambayya House.

Ugaigbe, T.B. (2010). Electoral Violence in Nigeria: Implications for Security, Peace and Development Peace and Conflict Monitor: University for Peace. Retrieved March, $18 \mathrm{http} / /$ www.monitor.update org/archioeve.cfm?id article $=697$.

Umar, M.Z. (2007). Nigeria and the Challenges of Democratic Consolidation. Sokoto: Ijabah Press.

Vanguard Newspaper. (2012). Lagos: February $15^{\text {th }}$ 